\title{
Public diplomacy and regional leadership struggles: the case of Saudi Arabia
}

\author{
Jens Heibach ${ }^{1}$ (D)
}

Accepted: 17 May 2021

(c) The Author(s) 2021

\begin{abstract}
In light of recent Saudi Arabian foreign policy, this article examines the valorization of public diplomacy in regional leadership struggles - a widely neglected topic in discussion on regional powers. Concentrating on regions with distinct power hierarchies, the literature offers nuanced explanations for how already-established regional leaders seek to maintain their position but only limited discussion of how ambitious states seek to assume leadership in the first place. The proposed binary set of coercive and persuasive strategies used by aspirant leaders does not capture the complexities of these regional leadership struggles. This article argues instead that aspirant leaders lacking the power assets to exclusively embark on either strategy become prone to resorting to a strategy mix combining elements of both coercion and persuasion. Because of the inconsistencies arising from applying such antithetical policies, however, public diplomacy significantly gains in importance as a magnifying and balancing tool amid this strategy mix.
\end{abstract}

Keywords Regional powers · Leadership struggle $\cdot$ Public diplomacy $\cdot$ Saudi Arabia

How do states buttress their claims to regional leadership? As we have come to live in a world where regions are critical in swaying global politics, this question has considerably gained in significance. This holds particularly true for regions marked by multiple, often overlapping conflicts between regional competitors capable of affecting the global security architecture. Beyond historical cases, one might think of Africa, where the competition between the continent's antagonistic powers has recently been acknowledged as 'an important feature of the African political landscape' (World Peace Foundation 2016: 16), and of the broader Asia region, which is becoming increasingly conflict-prone-with regional contenders such as China,

Jens Heibach

jens.heibach@giga-hamburg.de

https://www.giga-hamburg.de

1 German Institute for Global and Area Studies, Neuer Jungfernstieg 21, 20354 Hamburg, Germany 
Japan, Indonesia and India engaging in the redefinition of the regional order (Pajpaee 2017). Another case in point is the Middle East. ${ }^{1}$ While throughout much of its post-World War II history the region has been notorious for its weak institutions and for a plethora of inter- and intra-state conflicts, the 2011 Arab uprisings would lead to fierce competition over regional leadership between its major powers.

The strategies that states embark on to assume regional leadership have serious, real-world implications in and beyond the respective regions. Yet we know surprisingly little about how exactly states pursue their leadership objectives. As illustrated in detail below, the literature essentially suggests two ways to assume regional leadership: states can take over leadership, first, by coercing others into accepting their leadership position by deploying, or threatening to deploy, hard power or they can, second, persuade others to accept their leadership position on the basis of their leadership assets. These basic notions are of modest help in explaining the empirical dynamics of regional leadership struggles, however. Due to the structural features of bi- or multipolar regions, in which no state has sufficient either material or immaterial power capabilities to dominate its neighbours, the strategies of aspirant leaders tend to be multipronged and flexible, oscillating between ones that have elsewhere been attributed to empires, hegemonies and leaders (in the sociological sense). The employment of such a strategy mix, however, is inconsistent and mutually undermining, resulting in an incoherent foreign policy behaviour that is reminiscent of the often-stated 'ambiguous' foreign policies of established regional powers themselves (Harig and Kenkel 2017; Sauer et al. 2017; Serrão and Bischoff 2009). To make up for this, would-be leaders are prompted to invest effort in developing corrective strategies in accordance with the available resources.

Although rarely associated with the murky waters of regional conflicts, I assume that public diplomacy is thus a crucial tool in the strategic arsenal of aspirant leaders. This assumption is supported by a small yet growing body of the literature on the public diplomacy of regional powers. Çevik and Seib (2015) or Huijgh (2017), for instance, provide insightful analyses of the general features of the public diplomacy of Turkey and Indonesia, respectively, indicating how it is deployed to contribute to their regional and international prestige or to support their idiosyncratic goals. The increasing importance of public diplomacy is also illustrated by other cases too. India, for example, purposefully uses cultural diplomacy to back its 'Act East' policies (Singh and Sarwal 2017). And while Nigeria's bid for leadership in Africa has suffered from poor foreign policy articulations and an unfavourable international image (Ogunnubi and Okeke-Uzodike 2016), South Africa's claim to such leadership has been elevated by its 'symbolic representivity' of the continent in the eyes of the international community rather than by regional consensus (Alden and Schoeman 2015).

\footnotetext{
1 The Middle East is here considered to be 'constituted around an Arab core [...] flanked by a periphery of non-Arab states-Turkey, Iran and Israel—which are an intimate part of the region's conflicts and an integral part of its balance of power' (Hinnebusch 2003: 1).
} 
These and other studies ${ }^{2}$ demonstrate the meaning of public diplomacy for regional powers, including with respect to how it is used to support their regional and/or international standing. Yet they do not provide more detailed explanations for its deployment in leadership struggles. Hence, in this paper I attempt to show how public diplomacy is purposefully employed by states in conjunction with coercive and co-optive strategies to support their claims to regional leadership—or, more specifically, how public diplomacy is strategically used to balance the simultaneous deployment of hard and soft power. To this end, public diplomacy is here understood as 'the way in which both government and private individuals and groups influence directly or indirectly those public attitudes and opinions which bear directly on another government's foreign policy decisions' (Signitzer and Coombs 1992: 138). On the one hand, this definition acknowledges the role of non-state actors and is hence in line with more recent approaches in the field (Gilboa 2008). On the other, it facilitates a state-centric perspective and puts focus on the manipulative dimension of public diplomacy, both of which are central to the needs of this study and the scope of my argument. While the manipulative dimension is not necessarily contested by newer studies these works stress the interactive nature of 'modern public diplomacy', which is understood as 'persuasion by means of dialogue that is based on a liberal notion of communication with foreign publics' (Melissen 2005: 18; Huijgh 2016).

To elaborate on my arguments, I discuss Saudi Arabian regional policies under King Salman and his son Muhammad bin Salman (MbS), who-as crown prince, deputy prime minister, chairperson of the Council for Economic and Development Affairs and the Council of Political and Security Affairs, and minister of defence-is often seen as the de facto ruler of the Kingdom. Saudi Arabia represents a particularly appropriate case to study the strategies of would-be leaders. Although Riyadh has long harboured leadership claims, it has only recently begun to actively pursue this goal—which allows us to study its combined hard- and soft-power strategies in condensed form. Given its abundance of resources, including its fiscal potency, its multitude of soft-power instruments and its dominant position within the region's media landscape, Riyadh is able to run the full gamut of public-diplomacy tools, from cultural diplomacy to broadcasting. The sample period begins with the coming to power of MbS in January 2015 and ends with Jamal Khashoggi's murder in October 2018, which was a debacle for the public image of the Kingdom and MbS in particular-critically challenging hitherto established Saudi (public-diplomacy) strategies.

As for the chosen time period, and arguably beyond in fact, I assume that Saudi public diplomacy served three principal purposes: to produce and enlarge regional followership, that at the level of both regional elites and regional publics; to obfuscate the use of hard-power strategies, or rather the consequences thereof; and to retain and extend the support of extra-regional actors. I do not suggest that these findings are fully transferable to all regional leadership struggles. Conflict

\footnotetext{
${ }^{2}$ See the 2017 special issue in Politics \& Policy on 'Soft Power and Public Diplomacy in the IndoPacific' 45(5).
} 
constellations in other world regions vary — even if not always fundamentally — as do the resources that other aspirant leaders have available to invest in public diplomacy; not all embark on imperial, hegemonic and leader strategies, or they do so over a more extended period of time; last, their relationship with extra-regional actors may be less distinct than that between, for instance, Riyadh and Washington. What I do propose in the following, however, is that regional leadership struggles crucially valorize public diplomacy as a magnifying and balancing tool amid the strategy mix of aspirant leaders.

In the following section, I briefly discuss the meaning of 'regional leadership'. Hereafter, I specify my arguments concerning the strategy mix of aspirant leaders and detail how and why public diplomacy is a suitable tool with which to facilitate their ambitions. I then analyse Saudi Arabia's use of such diplomacy. To this end, I begin with a discussion of Riyadh's foreign policy in the aftermath of the 2011 regional uprisings as well as of some general aspects of its public diplomacy. Finally, I investigate how the Kingdom has strategically deployed its public-diplomacy tools to prove its leadership capabilities and to camouflage its hegemonic strategies in the Qatar diplomatic crisis and its imperial strategies in the war in Yemen, respectively.

\section{Regional powers and regional leaders}

The concept of 'regional powers' provides a good starting point for approaching the question of how states pursue regional leadership. Although there is no universally agreed upon definition hereof, regional powers are usually conceived of as states with superior power capabilities (in terms of military, economic and ideational resources; Nolte 2010: 893) belonging to a geographically delineated region (Østerud 1992: 12) within the boundaries of which they are able to wield decisive influence over other states (Buzan and Wæver 2003: 62). Some issues remain unresolved, though. As the concept has been derived from the study of rising powers such as Brazil, Russia, India and China (Hurrel 2006), which, with some give and take, have been seen as the dominant states in their regional systems, regional powers have often been treated as being tantamount to regional leaders. Yet it is anything but clear whether this is so (Prys 2010, 2012), as there are in fact 'few regions or sub-regions that demonstrate the clear dominance of a regional power' (Nolte 2010: 884).

Some hesitation is thus in order when equating regional powers with regional leaders, both empirically and conceptually (Frazier and Stewart-Ingersoll 2012: 69-74). First, whether or not we consider a given region to be dominated by a state depends on how one defines this very region and the members of the regional system, respectively. However, competing definitional criteria for regions abound (Volgy et al 2017), and cut-and-dried model regions often fail to adequately capture empirical dynamics when they ignore the self-identification of states; the peculiarities of processes in hybrid regions; and the possibility that liminal states may have stakes in more than one region.

Second, the distribution of power determines the number of regional powers in a given region and, ultimately, the issue of regional leadership (Mattheis 2021). The 
crucial question, then, is what constitutes state power, and how to assess its multiple sources so as to set the overall benchmark. While some scholars tend to focus solely on military and economic capabilities in this respect (e.g. Lemke 2002), the landscape of regional polarity may alter if dimensions of hard power are combined with those of soft power (Frazier and Stewart-Ingersoll 2012: 72-73). Connected to this is the question of why states pursue regional leadership despite limited material capabilities. Earlier works have often ignored this issue, assuming that regional leadership is but a consequence of a state's overwhelming material capabilities. Yet, pointing to the chasm between such stipulations and empirical observations, others have maintained that the aspirations ( $\mathrm{Nel}$ and Stephen 2010), the willingness (Cline et al 2011) or the self-perception (Lopez-Lucia 2015) of states vis-à-vis assuming leadership should take centre stage in analyses of why they claim the role of leaders and adapt their foreign policy behaviour accordingly.

All these points bear implications for the concept of regional leadership. 'Leadership'-just like 'hegemony'-is a fuzzy term defying precise definition, and both are often used interchangeably - notwithstanding their potential conceptual differences. ${ }^{3}$ Like hegemony, leadership connotes a 'situation in which one state is powerful enough to maintain the essential rules governing interstate relations and is willing to do so' (Keohane 1984: 34-35). Also like hegemony, leadership must be a relational concept—one characterizing the relationship between states (Jesse et al 2012). As it is understood here, military and economic capabilities are the inevitable prerequisites for leadership (Prys 2010: 485). Yet, to be more effective and sustainable, leadership must also involve immaterial power assets (Ikenberry and Kupchan 1990), such as the ability to influence others by means of soft power (Nye 2008a; Russet 1985) or-from a more sociologically inclined perspective- the ability to set the agenda, to persuade and to critically shape the wants and beliefs of others (Young 1991).

Therefore, leadership can be best conceived of as moving along a continuum between two extremes: At the minimal end thereof, leadership exists if there are no second-tier states who can act against the core interests of the leader without fearing serious consequences. At the other extreme, second-tier states follow not out of fear but because they are convinced of the leader's vision of (regional) order or because they have internalized the leader's norms and beliefs. As such leadership is not a static concept, nor is it a fixed state. It has been maintained that 'a key point to make about the leadership role is that it is often difficult to achieve success' (Frazier and Stewart-Ingersoll 2010: 741). Leadership should hence be understood as a process-based concept, 'an act that has to be unveiled by looking at political processes' (Nabers 2010: 51). This assumption is helpful when zooming in on the strategies employed by aspirant regional leaders.

\footnotetext{
${ }^{3}$ For an almost tautological use of both terms, see Gilpin (1981: 153) and Norloff (2017).
} 


\section{The meaning of public diplomacy in regional leadership struggles}

As stated, our knowledge about the strategies that states embark on to assume regional leadership is comparatively scant. Two fundamental strategies of aspirant leaders are commonly discussed. ${ }^{4}$ First, leadership is achieved via the overwhelming material capabilities of states, who must be prepared to employ these to be recognized as leaders (e.g. Lemke 2002; Hart and Jones 2010). Second, states become leaders because they are willingly accepted as such due to a foreign-affairs approach that rests upon amicable interactions, the articulating of a convincing regional vision or the provision of public goods (e.g. Cooper et al 1991; Pedersen 2002). ${ }^{5}$ These only provide a very basic notion of leadership strategies, one that barely does justice to the empirical dynamics found in many world regions.

Recent scholarship has begun to further address leadership struggles. Yet these works focus on predefined regions with clear regional hierarchies and, connected to this, act on the assumption of pre-established leadership positions, rendering them of limited value for our purposes. The literature on contested regional leadership, for instance, is enlightening as it fosters our understanding of how some regional powers 'project power or increase their influence in the region', proposing a set of four leadership types: namely, distributional, consensual, multilateral and ideational (Ebert and Flemes 2018a: 17). But it assumes an already-established leadership position, and it explicitly excludes the use of coercive strategies (Ebert and Flemes 2018 b). The former assumption, however, is analytically problematic as it conceives of leadership not as a process-oriented concept but rather as an accomplished condition. The latter, in turn, is empirically delicate, as there is ample proof of regional powers resorting to coercion (Prys 2010; Wigell 2016).

It has long been disputed that regional powers are all cooperative, benevolent and inclusive in their conducting of regional affairs (Prys 2012: 26-36). In an effort to conceptualize the scope of their foreign policy behaviour, Sandra Destradi (2010), for instance, has identified three ideal-typical regional strategies, ranging from those attributable to 'empires', 'hegemons' and 'leaders' (understood in a purely sociological sense), respectively: imperial ones are characterized by the unilateral pursuit of national self-interest; they rest on coercion, with the 'decisive distinguishing factor' being 'the threat or use of military power' (ibid.: 912). Hegemonic strategies, then, are also exclusively motivated by the end of attaining self-interested goals. However, the means employed vary extensively (ibid.: 917). Destradi chooses to differentiate between coercive (or hard) and benevolent (or soft) hegemons, with the former resorting to strategies such as 'sanctions, threats, political pressure, and, to a lesser extent, inducements' vis-à-vis other states (ibid.: 918). Soft hegemons, in turn,

\footnotetext{
4 Seçkin Köstem (2018: 727), too, stresses the scarcity of literature dealing with how states pursue regional leadership. Yet, while focusing on economic integration as a strategy to buttress states' claim to leadership, he also limits himself to these two fundamental strategies, contrasting Russia's 'coercive tools' with Turkey's 'more liberal tools of leadership' in fostering regional economic cooperation.

5 Some authors view these two strategies to be mutually reinforcing and as being used in combination. See, for instance, Hinnebusch (2013) or Frazier and Stewart-Ingersoll (2010).
} 
pursue strategies aimed at the reshaping of other states' norms and values through, for instance, ideological persuasion (ibid.: 920).

Last, and resembling the strategies of soft hegemons, leadership strategies are based on the leader's 'engagement in a socialization process with the aim of creating shared norms and values and generating "true" followership' (ibid.: 924). What distinguishes leaders from hegemons, though, is that the former guide other states to implement common objectives, whereas the latter attempt to realize their own self-interested goals by presenting them as common objectives (ibid.: 921). While Destradi, too, acts on the assumption of an already-established leadership position, her approach seems to be more fitting for capturing the dynamics of leadership struggles, particularly as she does not deem the above strategies to be mutually exclusive. Rather, she states that ' $[\mathrm{m}]$ ost probably, one would find that a regional power pursues a simultaneous policy mix of different strategies' (ibid.: 929). Indeed, a glimpse at current leadership struggles in East Asia, South Asia, Africa and the Middle East suggests that regional powers often embark on a number of strategies simultaneously.

The problem, though, is that the simultaneous employment of imperial, hegemonic or leader strategies is inconsistent, and results in actions that undermine one another. For one thing, it is implausible for potential followers to, for instance, believe in allegedly shared interests and values if the would-be leader chooses to coerce one or more potential follower into complying with its demands-ones that are at odds with their own interests or values. For another, it would be a more constructive approach for the would-be leader in the long term to channel limited resources into the consolidation of one strategy instead of concurrently expending them on several non-beneficial ones. As the ensuing discussion of the Saudi Arabian case suggests, one expedient way to cope with the inconsistencies in the short or medium term is the concerted use of public diplomacy.

This may not be surprising, as such diplomacy is a viable tool for states to resort to in order to back up their foreign policy aspirations as well as to make up for their deficiencies. Since the first quarter of the last century, the strategic use of public diplomacy has become an accepted and widely used foreign policy tool (Kunczik 2009: 775), supporting states in achieving their objectives (Signitzer and Wamser 2006; L'Etang 2009). To this end, states use various instruments to engage with strategic foreign publics, including advocacy, broadcasting, cultural diplomacy, nation branding and public relations (Gilboa 2008: 58). States have also become increasingly prone to resorting to PR agencies for counsel in their attempts to reach foreign publics. This particularly applies to developing countries, who-due to the lopsided nature of the global media and their lack of experience with social and political processes in economically developed peers-are often susceptible to distorted representations in the mass media (Srimamesh and Verčič 2009: 15). Owing to the rising importance of the latter, the mediation of foreign policy-meaning the 'systemic, organized attempts by governments to exert as much control as possible over how state policy is portrayed in foreign media' (Tago 2017)—occupies a central position in public diplomacy in general.

In what follows, however, I argue that only by combining analyses of the regional policies and public diplomacies of aspirant leaders can we fully understand how 
they seek to fulfil their leadership objectives. The novelty of my argument is twofold. First, it is because they lack sufficient coercive and persuasive power that aspirant leaders are particularly prone to embarking on a mix of imperial, hegemonic or leader strategies simultaneously. Second, it is because of the inconsistencies generated by the use of this strategy mix that they need to concomitantly step up their public-diplomacy efforts.

Some remarks are in order regarding the first part of the argument before elaborating on the second one. To begin with, the mixing of strategies need not necessarily be a bad thing in itself. The notion of 'smart power', developed by Joseph S. Nye based on the model of the US superpower, in fact maintains that the most effective way of meeting a foreign policy target is to employ an integrated strategy combining hard and soft power. Yet apart from the 'contextual intelligence' that is needed to produce such a strategy (Nye 2009: 162), smart power presupposes the availability of sufficient hard- and soft-power resources and their combination 'in ways that are mutually reinforcing' (Wilson 2008: 115). Neither of the two is given in situations that prompt would-be leaders to step up their public-diplomacy efforts. Furthermore, it is noteworthy that public diplomacy today is often discussed in connection with Nye's soft-power approach (e.g. Hocking 2005). Nye defines soft power as 'the ability to affect others through the co-optive means of framing the agenda, persuading, and eliciting positive attraction in order to obtain preferred outcomes' (2011: 20-21) — note here the overlap with Destradi's notion of leadership. According to Nye (2004: 11), soft power rests on three main resources: a country's culture, its political values and its foreign policies. Yet one of the approach's major conceptual problems is that these resources are not all under the direct control of the government (ibid.: 14, 17; Kearn 2011: 78). One major-if not the sole-tool available to governments to coherently sway a nation's 'attractiveness' in the eyes of others is thus public diplomacy (Blechman 2004: 680), the meaning of which is stressed by Nye (2008b) himself-also with regard to smart power.

The rest of this section will be tailored to the analytical needs of the paper instead of providing a general discussion of public diplomacy. To reiterate the second part of the argument, I propose that public diplomacy becomes both a magnifying and balancing tool amid the strategy mix of aspirant leaders. Hence, the corresponding public-diplomacy strategies are geared towards accompanying this mix-either by reinforcing those strategies or by attenuating their contradictory effects. Consequentially, these public-diplomacy strategies are mainly of a short- and medium-term nature.

Gilboa's (2008: 72) suggestion to distinguish between the long-term, intermediate and immediate dimensions of public diplomacy is instrumental in this regard, including with respect to the means that one can attribute to each dimension. While long-term strategies such as cultural diplomacy are generally targeted at creating better relations with other nations, intermediate ones are intended to proactively planand implement—-specific foreign policy moves or to address a specific image crisis. PR campaigns, conducted, for instance, via the media with or without the support of related agencies, would rank among the crucial means here. At the immediate level, public diplomacy seeks to react to developing events - so as, for instance, to limit damage via various methods of news management. To be sure, one probably finds 
all these strategies in the public-diplomacy repertoire of aspirant leaders. However, the long-term strategies would not be directly connected to leadership struggles as they, first, may predate the state's claim to leadership and, second, are relatively unfit to be adapted to changing conflict dynamics.

A final remark should be made on the target audiences. While it is safe to assume that the primary target audience are regional publics, the case of South Africa's leadership claim suggests that international audiences-particularly those of great powers-may at times be as important as regional ones (Alden and Schoeman 2015) - all the more so if the aspired-to leadership position in the region is but a stepping stone to gaining recognition at the global level (Lebov 2008: 543). Beyond that, more recent approaches alert us to the domestic dimension of public diplomacy, arguing that the gaining of support at home for a state's policies abroad is indeed a key element of public diplomacy (Huijgh and Byrne 2012). Arguably, this is particularly relevant for regimes whose domestic legitimacy is heavily built on a leadership claim - as is the case, for instance, with Saudi Arabia's claim to leadership in the Muslim world. Moreover, as will be seen, the Saudi case is peculiar in that one cannot always analytically distinguish between the domestic and regional audiences of Riyadh's mediation strategies, since much of the output from Saudi-owned, panArab media outlets is consumed by both Saudi and non-Saudi Arabs alike.

\section{Saudi Arabia's bid for regional leadership}

Until recently, Saudi foreign policy had been characterized as 'remarkably consistent' (Gause 2011: 169), dodging open confrontation while targeted at preserving the domestic and regional status quo (Partrick 2016: 374). A direct link has been established between the Kingdom's 'pragmatic' (Nonneman 2005: 339) regional policies and the 'serious inherent limitations' of its foreign policy, mainly with regard to its relative military weakness (Peterson 2002: 30; Hertog 2011). Its foreign policy tools have hence been restricted to the use of financial rewards (Farouk 2020; Gause 2011: 178); soft power (Gallarotti and Al-Filal 2012); conflict mediation (Kamrava 2013; Rieger 2016); and the dissemination of Wahhabism, including the provision of direct support to Islamists in and beyond the region (Commins 2006). To safeguard its security interests, Saudi Arabia has employed an omnibalancing strategy, meaning the simultaneous balancing of threats and resources within and between the domestic, regional and global levels, and has relied greatly on regional and international allies to carry this out—most notably the USA (Nonneman 2005: 319).

In the wake of the 2011 Arab uprisings, however, Saudi foreign policy would experience drastic changes. The country has increasingly resorted to using military power, sectarian politics and sanctions or other restrictive measures to interfere with the domestic affairs of other states (Al-Rasheed 2011, 2014; Sunik 2018). Often a mixture of reasons is advanced to explain this newly assertive stance, with scholars pointing to changes at the international, regional, subregional and domestic levels (Al-Tamamy 2012). Another approach that has been applied to explain recent Saudi foreign policy behaviour in its geopolitical neighbourhood, and towards the Arab Gulf states in particular, considers the Kingdom an 'authoritarian gravity centre' 
(AGC). According to the approach's underlying rationale, Saudi Arabia is a state that is willing and able to apply pressure and to disseminate autocratic ideas, norms, and practices, and that acts as a model for the countries in its geopolitical proximity (Zumbrägel and Demmelhuber 2020: 52). The AGC approach has been developed to include the foreign policy of authoritarian states as an additional, and indeed vital, instrument of authoritarian power consolidation by treating AGCs as states that actively promote autocracy or act as sources of autocratic diffusion (Kneuer and Demmelhuber 2016). It thus acknowledges a broad range of strategies used by such states, including Saudi Arabia, that manifest the aforementioned mix of imperial, hegemonic and leadership methods. And while AGCs are held as conceptually distinct from regional hegemons, the approach does not exclude the possibility of a state simultaneously being an AGC and a regional hegemon, or for that matter an aspirant regional leader (ibid.: 8). In fact, Demmelhuber (2019) agrees with most other scholars that Riyadh is bent on assuming regional leadership. This objective, however, has met with serious impediments. Above all, it has been challenged by Iran and Turkey (Aras and Falk 2015). As argued above, Riyadh's recent employment of extremely diverse foreign policy strategies towards the region, ones often characterized as 'erratic' (Al-Rasheed 2018: 248), must be understood against the backdrop of its struggle for leadership therein. That, too, is the case with its intensified public-diplomacy efforts.

Although public diplomacy has recently witnessed a boost under MbS, its strategic use very much predates his coming to power. Concerning PR campaigns in the USA, for instance, Saudi Arabia has even been designated a 'pioneering country' given that it was already in the early 1950s employing PR firms to lobby Congress or the White House (Al-Yasin and Dashti 2008: 355, 357). In line with the above suggestions, it is instrumental to analytically separate, and briefly discuss, Riyadh's long-term, intermediate and immediate public-diplomacy strategies at this point. To begin with, the Kingdom's global funding of conservative strands of Islam or of academic institutions (Sokolove 2019) would be the prime examples of its longterm strategies. Its hiring of PR firms or the concerted PR campaigns conducted via its media outlets would be located at the intermediate level meanwhile. Lastly, situated at the immediate level, Saudi Arabia among others resorts to Saudi-controlled media outlets, as was the case after the murder of Jamal Khashoggi (Hall 2019), and increasingly so to cyber tools such as Twitter too (Jones 2020).

Still, it is often difficult to draw clear-cut distinctions between long-term and intermediate strategies, particularly concerning the mediation of Saudi foreign policy. This is because Riyadh has built a complex media empire on the basis of subsuming most Arab newspapers-including the widely read pan-Arab ones al-Hayat and al-Sharq al-Awsat-as well as satellite TV channels such as the pan-Arab alArabiya that are part of Saudi-owned media networks like the Arab Radio and Television entertainment network (ART), the Middle East Broadcasting Corporation (MBC) or Orbit (Kraidy 2021). While attempts to exert control over the Arab media have hitherto been interpreted as efforts 'to control the flow of information [...] and assure positive coverage of its politics and society' (Hammond 2007), recent analyses suggest that the Kingdom has begun to use its media dominance more purposefully to back its leadership objectives (Yaghi 2017: 51). 
In the following, I will demonstrate how Riyadh has oscillated between imperial, hegemonic and leadership strategies and sought to capitalize on its abundant public-diplomacy resources to facilitate — or indeed shroud — these approaches. I set out to analyse the mediation of Saudi leadership claims. Here, I focus less on the Kingdom's leadership strategies as such but rather on how its claimed leadership assets are substantiated via Saudi-controlled media outlets. Hereafter, I look at Saudi public-diplomacy measures during the first year of the Qatar crisis, which I treat as a case of Saudi hegemonic strategies. Lastly, I discuss Saudi public diplomacy regarding the war in Yemen, which represents a Saudi imperial strategy. All three cases hone in on the intermediate dimension of Saudi Arabian public diplomacy.

\section{Mediating Saudi leadership assets}

Based on a review of the corresponding coverage in the pan-Arab media outlets under Riyadh's direct or indirect control, I assume that three core messages served to add substance to Saudi leadership claims. By portraying itself, first, as a pacemaker for reform and, second, as a regional protector, Riyadh sought to present itself as a provider of public goods and of a convincing regional vision. Third, by highlighting its followers, Riyadh aimed to emphasize its already-established leadership position, thereby diverting attention from its more controversial policies - ones which might have prompted regional publics to question its leadership qualities. ${ }^{6}$

Leadership through reform: It is difficult to dismiss the record of reforms that the Kingdom has witnessed since 2016. The crown prince personified the recent social and economic changes, and he used the image of a young reformer to bolster his legitimacy among the overwhelmingly young Saudi population as much as he promoted it outside the region too-for instance, during state visits to key Western allies, which were usually preceded by concerted PR campaigns (Spanier 2018). Notwithstanding criticisms concerning the absence of political openings or the sobering record of human rights violations inside the Kingdom, some of these reforms have the potential to convey a broader vision of change in the region. The Saudi-controlled pan-Arab media at least portrayed the Kingdom as a pacemaker for reform, with the main rationale being that these initiatives were not just addressing Saudi issues but major challenges in the Middle East more generally (Al-Qawi $\mathrm{i}$ 2018; Al-Muqrin 2018).

For instance, the crown prince's advances in the economic realm-including the 'world's most ambitious project' Neom ${ }^{7}$ or 'Vision 2030', which received far greater mention than comparable regional programmes in the media ${ }^{8}$-were implicitly

\footnotetext{
${ }^{6}$ Note the intersection of different audiences here. Besides regional publics, these messages were also directed at the domestic audience to consolidate the crown prince's authority at home.

${ }^{7}$ A planned transnational mega city and economic zone in Tabuk.

8 An Advanced Google Search conducted on 30 April 2018 on www.alarabiya.net yielded 7,460 results for the Saudi Vision 2030 on al-Arabiya's Arabic website and 101 results on its English one. In contrast, the Abu Dhabi Vision 2030 was mentioned once (Arabic; three results on the English website), the Kuwait Vision 2035 twice (Arabic; no results on the English website). Note that the Saudi Vision 2030 was announced in April 2016, the Kuwait Vision 2035 in January 2017. The Abu Dhabi Vision 2030 dates back to 2007, while the Abu Dhabi Economic Vision 2030 was announced in March 2017. All
} 
or explicitly depicted as role models for economic reform that stood in contrast to the long-standing inability of other regional regimes to address their economic malaise (Al-Mazru'i 2017; Al-Minshawi 2016). Furthermore, the intense coverage of recent social and religious reforms such as the partial lifting of gender segregation, the introduction of cinemas or the announcement of a return to a moderate from of Saudi Islam were addressing, and making the Saudi leadership palatable to, those publics that have hitherto been critical of the Kingdom. These included not only women and religious minorities but also the youth, and thus large parts of the regional populace. It was therefore common practice in Saudi-dominated media outlets to highlight Saudi reforms, to depict the Kingdom as a 'youth force' and to discuss these characteristics against the backdrop of broader regional challenges (Al-'Awwad 2017; Al-Rumayhi 2017; Al-'Utaybi 2015; Salih 2017).

Leadership through protection: Riyadh substantiated its claim to leadership by vilifying its competitors and by promoting itself as the sole guardian against the threats emanating from them. Much research has been done on the sectarian narratives in the Saudi-controlled media that targeted Shiites, the Muslim Brotherhood and their supporters - most notably Iran and Turkey (Yaghi 2017). These narratives were complemented with reminders to the Arab audience of the non-Arab nature of potential Iranian or Turkish hegemons, including reminiscences about past instances of non-Arab rule by the Ottomans (Al-Sayyid 2018; Al-Zami ${ }^{\circ}$ 2017) or the Safawids (Matthiesen 2015: 8) over the region's Arab core. Corresponding comments by high-ranking policymakers such as Minister of Foreign Affairs 'Adil al-Jubayr, who asserted that MbS's plan to transform Saudi Arabia into a powerful state was motivated by his endeavour to contain a newly arising Persian Empire, were also published (Al-Arabiya 2018); as were ones from MbS himself, who publicly referred to Iran's Supreme Leader 'Ali Khamene'i as the 'new Hitler of the Middle East' (AlArabiya 2017a) or warned of a 'Muslim axis of evil' consisting of Iran, Turkey and the Muslim Brotherhood (Hussayn 2018). The key message was that the Kingdom is the sole protector against regional evil, putting forth its 'vision of light' against Iran's 'vision of darkness' (Al-Arabiya 2018).

Illustrating followership: Leaders need followers, and followers make leaders. Saudi-controlled media outlets therefore accentuated the Kingdom's lead position in approaching issues of regional and global relevance and detailed the number and breadth of its supporters. One example was the reporting on the Saudi-initiated Islamic Military Alliance to Fight Terrorism (IMAFT), founded December 2015, which comprises 41 Muslim states. IMAFT was also a useful tool with which to illustrate Saudi seriousness about countering terrorism and to demonstrate the number of states willing to follow Riyadh's call (e.g. Al-Arabiya 2017b). To facilitate positive coverage of the Saudi-led 'Muslim NATO' and to fend off criticism

Footnote 8 (continued)

reform programmes seek to diversify the economy and reduce its dependence on the oil sector. Search terms: 'Vision 2030' (Arabic 'ru’ya 2030'), 'Abu Dhabi Vision 2030' (Arabic 'al-ru'ya al-iqtisadiyya 2030 li-imara Abu Dhabi'), 'Kuwait Vision 2035 (Arabic 'ru’ya al-Kuwait 2035'); search period: 31 January 2017-1 February 2018. 
concerning, for instance, its participation in the Yemen war, Riyadh contracted the leading international PR firm Burson-Marsteller (Merrill 2017). While there were a number of other examples of Riyadh's endeavour to illustrate its followership in and beyond the region, the most revealing depiction of Saudi leadership in the media was in connection to US President Donald Trump's visit to the Kingdom in May 2017. State visits have been recognized as a significant public-diplomacy activity, and Trump's visit was well suited to showcasing Riyadh's leading position to a regional and global audience- not only because it was his first-ever foreign trip as president but also because 54 Muslim heads of state had accepted the invitation to partake in the 'Arab Islamic American Summit' during Trump's stay.

Ultimately, leaders deliver by convincing their followers that their goals coincide, and that their methods of attaining these are the best way forward. In that sense, the Saudi mediation strategies depicted above sought to reinforce the Kingdom's leadership claim. Yet when assessing Saudi Arabia's proposed leadership, Middle East states take its overall performance into consideration-including its use of hegemonic and imperial strategies. These rest, however, on imposition and coercionbehaviours inherently counterproductive to establishing followership. If aspirant leaders still apply such strategies regardless, they must either be framed as mandatory and as beneficial to other states or downplayed and concealed. To this end, public-diplomacy measures become indispensable. Concerning the following two cases, the diplomatic row with Qatar and the war in Yemen, Saudi mediation efforts towards Middle East publics relied on a mix of exactly these methods to balance the undermining effects of its coercive strategies vis-à-vis the Saudi leadership claim. ${ }^{9}$ In both cases, however, strategic global publics were as important as regional ones, since the geopolitical and economic ramifications of the conflicts could have easily transcended regional borders. Moreover, in both cases the Kingdom depended on the backing of crucial Western allies-most notably the USA. Therefore, I subsequently focus on the Saudi public-diplomacy strategies employed to influence strategic global publics and, most importantly, to either win (the Qatar crisis) or not lose (the Yemen war) US support.

\section{Framing hegemonic strategies: the Qatar diplomatic row}

Being among the more audacious foreign policy moves Saudi Arabia took between 2015 and 2018, the conflict with Qatar epitomized a hard hegemonic strategy. In June 2017, a coalition involving the United Arab Emirates, Bahrain and Egypt under the leadership of Riyadh cut off diplomatic relations with Doha and, in a concerted effort, imposed a land, air and sea blockade on the Gulf state. These measures aimed to force Qatar to accept a 13-point ultimatum, with the list of demands including stipulations that Doha ceases its support for Islamic terrorism, breaks its ties with

\footnotetext{
${ }^{9}$ For mediation strategies in the Yemen war, see Matthiesen and Sons (2016). Concerning the Qatar conflict, Saudi-controlled media echoed the official reproaches. In October 2017, the crown prince stated that the Qatar crisis was 'a very, very, very minor problem for the Kingdom. We are committed to the security of our country and far from [causing] any disturbances' (Al-Hayat 2017).
} 
Iran and closes down Al Jazeera - the popular, Qatari-funded broadcaster and main rival to a Saudi media monopoly in the region (Sciutto and Herb 2017). Qatar's regional policies had long been at odds with those of Saudi Arabia, and the conflict between the two eventually peaked in the aftermath of the 2011 Arab uprisings when Doha stepped up its systematic support for the Muslim Brotherhood-thereby overtly challenging the position of Riyadh and its most important Gulf ally, Abu Dhabi.

The ultimatum sought to put an end to Doha's independent foreign policy and to force Qatar into accepting Riyadh's supreme authority in regional affairs. The US position in this historic feud, which essentially centred on 'a substantial surrender of [Qatar's] national sovereignty' (Sick 2017), was critical given that Qatar had been a long-standing strategic US ally and host of the US Central Command's Forward Headquarter and the Combined Air Operations Center in addition to roughly 10,000 US forces. Getting the Trump administration to back, or at least not interfere with, the Kingdom's move against Doha was therefore paramount.

The blockade appeared to have US support at first. However, because the State Department and large parts of Congress were concerned about the negative consequences hereof for US interests, Riyadh attempted to influence strategic publics in the US - to this end building on a complex infrastructure of local PR and lobbying actors working on its behalf. ${ }^{10}$ Following Washington's acceptance of the Iran nuclear deal in 2015, more than two dozen lobbying and PR firms had registered with the US Department of Justice (DOJ) under the Foreign Agents Registration Act (FARA) to work for the Kingdom in discrediting Iran's regional policies. These lobbyists were also used to foster anti-Qatar sentiment, especially among US policymakers (Luck 2016). In this context, the Saudi American Public Relations Foreign Affairs Committee (SAPRAC), a pro-Saudi organization registered in 2017 as a foreign agent (DOJ n.d.a), became publicly known in July 2017 for launching anti-Qatar television ads, Twitter-based advocacy campaigns and for operating The Qatar Insider - a website claiming to be 'the comprehensive source for information on the truth about Qatar's funding, activities and support for terrorist and extreme Islamist groups'. ${ }^{11}$ To favourably present Riyadh's position in the Qatar row to US journalists, think tanks and policymakers, SAPRAC additionally contracted the Podesta Group, a Washington-based lobbying and PR firm, to exclusively focus on Qatar and work on denigrating its image. The corresponding agreement between the Podesta Group - commissioned to develop 'supporting documents and other materials as needed, such as fact sheets and profiles of Qatar's support for and financing of terrorism' and to publicly foster 'Saudi Arabia's role as a regional and international security leader' (DOJ n.d.b: 15)—and SAPRAC reflected not only the Kingdom's agenda in the conflict in question but also its wider ambitions in the region.

\footnotetext{
${ }^{10}$ Other institutions that joined in the anti-Qatar campaign included, for instance, the Saudi-funded Arabia Foundation in Washington, D.C. See Arabia Foundation (2017).

11 See: https://theqatarinsider.com/about-tqi/. Qatar responded by setting up its own website: https://liftt heblockade.com/.
} 
A preliminary assessment of Saudi strategies up until October 2018 should stress the limited effects of both the blockade and the PR efforts. Doha not only defied Saudi demands but also grew closer to Iran and Turkey. Also, the campaign appears to have had no impact on Washington's stance in the conflict. On the contrary, Qatar and the US renewed-indeed elevated - their strategic partnership (US Department of State 2018). Whether the US's unwillingness to support Riyadh's position was due to higher-ranking security interests, the quality of the Saudi campaign or that of Qatar's counter-campaign cannot be answered conclusively. Yet at an estimated total cost of US\$1.5 billion, Saudi PR efforts appear to have been inefficient from a cost-benefit perspective (Hassan 2018).

\section{Camouflaging imperial strategies: the war in Yemen}

On 25 March 2015, Saudi Arabia unilaterally launched a military attack on Yemen after proclaiming its determination to restore the rule of President 'Abd Rabbo Mansur Hadi and to save its neighbour from the Houthi movement, which had by then taken over large parts of the country. The military campaign was instantly joined by a coalition of Arab states including Bahrain, Egypt, Jordan, Kuwait, Morocco, Qatar, Sudan and the UAE, with France, the UK and the USA providing logistical support and arms. The Saudi intervention was unprecedented, and the clearest indication of Riyadh's newly assertive regional policy-which has seen it not shy away from using imperial strategies to attain its goals.

Several explanations have been offered for this. While some analysts have pointed to the changes in Saudi leadership and the rise of $\mathrm{MbS}$, seen as being behind the intervention (Mazzetti and Hubbard 2016), the Saudi government from the outset justified the war with claims of Iranian expansionism, portraying the Houthis as proxies receiving orders and military support from Tehran. Although the war certainly boosted Iran's involvement ex post, scholars have argued that Tehran's backing of the Houthis was negligible when hostilities first commenced (Juneau 2016) an assessment that was shared by the UN Panel of Experts on Yemen in 2017 (UN Security Council 2017). The most compelling accounts hence interpret the (initial) campaign as status-seeking behaviour, holding that Riyadh expected a quick military victory and went to war 'in order to assert and confirm its status as a leading power in the region' (Darwich 2018: 127; Darwich 2020).

Contrary to these expectations, however, the war soon came to undermine Riyadh's bid for greater prestige. Unable to achieve victory and demonstrate its military credentials, it became stuck in a quagmire. The magnitude of civilian suffering - prompted by the coalition's indiscriminate air bombing and its near-total blockade on food, medical and fuel supplies entering Yemen, leading to the 'world's worst humanitarian crisis' (UN Office at Geneva 2018) — not only threatened to hurt Riyadh's image as regional leader but also to jeopardize the support provided by its Western allies, including the USA (de Luce and Gramer 2018). Whereas domestically and regionally the Kingdom relied on its media outlets to maintain popular support, at the global level it sought to uphold the sovereignty of interpretation via various public-diplomacy tactics. Among these, first, the 'tactic of withdrawal' 
(Kunczik 2009: 785-786)—meaning the attempt to keep Yemen out of international headlines by heavily restricting access to, or embedding, ${ }^{12}$ independent journalistswas effective, as it reduced the coverage relative to that of, for instance, the war in Syria (Nichols 2017).

Second, the Kingdom tried to dilute responsibility for the humanitarian crisis, highlighting its aid to Yemen by, among other things, cooperating with prestigious international aid agencies (McVeigh and Summers 2018) — a strategy that humanitarian organizations identified as a 'war tactic' (International Rescue Committee 2018). Third, in an attempt to mobilize anti-Iranian attitudes among Western policymakers, Riyadh sought to exaggerate Tehran's role. Given the importance of Washington's support, the Kingdom contracted PR firms to shape the narrative circulating in the US about the war. In particular, the Qorvis MSLGROUP (DOJ n.d.c) and Brownstein Hyatt Farber Schreck, LLP (DOJ n.d.d) were tasked with promoting Riyadh's official reading of the war to Members of Congress and a wider US public by concentrating on 'Iranian aggression' and providing information on 'Saudi humanitarian aid to the people of Yemen' or efforts concerning the 'reduction of civilian casualties'. The extent to which this campaign actually influenced US decision-making or media coverage is impossible to measure. It is noteworthy, however, that the conflict was predominantly framed as a proxy war in the media and that 'Iran's sinister activities in [...] Yemen' were cited inter alia by Trump in justifying his termination of the Iran nuclear deal in May 2018 (White House 2018).

\section{Conclusion}

In this article, I have examined the valorization of public diplomacy in regional leadership struggles. The oft-suggested binary set of coercive and persuasive strategies of aspirant leaders provides only an inchoate take on the empirical dynamics found in many world regions. It is because they lack the necessary material and immaterial power assets to exclusively embark on either strategy that aspirant leaders become prone to resorting to a strategy mix combining elements of coercion and persuasion. Drawing on the regional powers literature, I have suggested that this mix may include the use of imperial, hegemonic and leader strategies, and that aspirant leaders may feel tempted-or indeed forced-to adopt these strategies simultaneously. Because of the inconsistencies arising from simultaneously applying such antithetical policies, public diplomacy gains considerably in importance as a magnifying and balancing tool amid this strategy mix.

The case study of Saudi regional policies under King Salman and his son MbS has sought to discuss and elaborate on these arguments. Covering the period between the former's ascension to the throne in January 2015 and the murder of Jamal Khashoggi in October 2018, it illustrated, first, how the mediation of Saudi domestic and foreign policies via Saudi-owned media outlets served to back up the Kingdom's claim

\footnotetext{
12 See, for example, the reporting on the Saudi-held city of Ma'rib in a number of key international media outlets such as The New York Times, Der Spiegel or Le Monde in late 2017 and early 2018.
} 
to regional leadership on the one hand and to balance the negative consequences of its coercive strategies regarding this claim on the other. The analysis of the Qatar crisis and the war in Yemen, respectively, focused on how Saudi public-diplomacy strategies attempted to influence strategic global—and, most importantly, US—publics to win support for its hegemonic policies vis-à-vis Doha and its imperial policies towards Yemen. While Saudi public-diplomacy measures were multipronged in both cases, Riyadh mainly capitalized on a complex infrastructure of PR campaigns and lobbying actors in the Qatar crisis. Concerning its public-diplomacy strategies towards Yemen, Saudi Arabia sought to manipulate the international news coverage on the war by limiting journalists' access and by highlighting its humanitarian assistance to the country. Beyond this, the Kingdom drew on contracted PR companies to direct international attention to Iranian involvement-also as a way to justify its own role. In a nutshell, then, Saudi public diplomacy served three major purposes, all of which were critical to supporting and maintaining the Kingdom's bid for regional leadership: the production and enlargement of a regional followership; the obfuscation of its imperial and hegemonic strategies; and the retaining and extension of vital support from extra-regional actors, most importantly the USA.

Whereas some of this article's findings may be peculiar to the latest Saudi foreign policies in and beyond the Middle East, there is a strong case for further future research on the topic. As outlined, ambitious regional powers may not, for instance, resort to military power but merely fluctuate between hegemonic and leader strategies; they do not need to have the same amount of public-diplomacy resources or the same choice of instruments as Saudi Arabia either. The public-diplomacy toolkit has evolved rapidly, with its costs reduced and its large-scale strategic use rendered more attractive to less wealthy actors-including non-state groups (Bos and Melissen 2019). Yet as was pointed out at the outset, studies on cases such as India, Indonesia, Nigeria, South Africa or Turkey concur in their recognition that public diplomacy has become an increasingly vital tool for regional powers and aspirant regional leaders. Further research on how public diplomacy is employed in conflict dynamics other than those in the Middle East would therefore foster our theoretical and empirical understanding of the formation and development of regional leadership struggles.

Another avenue for further research arises from the emerging field of study on the international dimensions of authoritarianism (e.g. Bank 2017; Hall and Ambrosio 2017; von Soest 2015). While the key interest guiding this research agenda ultimately differs-i.e. authoritarian consolidation as opposed to regional leadershipthere are important overlaps with the study of regional leadership struggles. As has been briefly discussed with respect to the AGC concept, both aspirant leaders and autocracy promoters tend to embark on a strategy mix that calls for accompanying public-diplomacy measures to win favour with target audiences at the domestic, regional and international levels. Attracting these audiences, either by way of actively promoting autocratic elements or by building international autocratic linkages, is generally regarded as essential for the survival of authoritarian regimes since it facilitates 'preferences for status quo politics both among international partners and domestic constituencies' (Tansey et al. 2017: 5). How autocratic protagonists 
strategically deploy public diplomacy to influence diverse audiences is a promising pathway in future research on the international dimension of authoritarianism.

Funding Open Access funding enabled and organized by Projekt DEAL.

\section{Declaration}

Conflict of interest The corresponding author states that there is no conflict of interest.

Open Access This article is licensed under a Creative Commons Attribution 4.0 International License, which permits use, sharing, adaptation, distribution and reproduction in any medium or format, as long as you give appropriate credit to the original author(s) and the source, provide a link to the Creative Commons licence, and indicate if changes were made. The images or other third party material in this article are included in the article's Creative Commons licence, unless indicated otherwise in a credit line to the material. If material is not included in the article's Creative Commons licence and your intended use is not permitted by statutory regulation or exceeds the permitted use, you will need to obtain permission directly from the copyright holder. To view a copy of this licence, visit http://creativecommons.org/licen ses/by/4.0/.

\section{References}

Alden, C., and M. Schoeman. 2015. South Africa's symbolic hegemony in Africa. International Politics 52 (2): 239-254.

Al-Arabiya. 2017a. Muhammad bin Salman: murshid Iran Hitler jadid fi-1-sharq al-awsat. 24 November. https://bit.ly/2FjBiDf. Accessed 28 Jan 2020.

Al-Arabiya. 2017b. Al-tahaluf al-islami.. tasmim 'ala ijtithath al-irhab. 27 November. https://bit.ly/ 2BgNTWa. Accessed 28 Jan 2020.

Al-Arabiya. 2018. Al-Jubayr: Muhammad bin Salman yurid tahwil al-Sa udiyya ila dawla qawiyya. 24 January. https://bit.ly/2BsIMSG. Accessed 28 Jan 2020.

Al-'Awwad, M. 2017. Al-dawla al-sa'udiyya al-jadida: quwwa shabba .. ru’ya iqtisadiyya mustanira. 'Ukaz, 30 January. https://bit.ly/2FmReoh. Accessed 28 Jan 2020.

Al-Hayat. 2017. Muhammad bin Salman: Qatar qadiyya saghira jiddan. 26 October. https://bit.ly/2joqL hU. Accessed 28 Jan 2020.

Al-Mazru i, F. 2017. 'Ardh 'ru’ya 2030' ka-namudhaj mi yari li-iqtisadiyat duwal al-majlis. Al-Jazira, 27 March. http://www.al-jazirah.com/2017/20170327/ec2.htm. Accessed 28 Jan 2020.

Al-Minshawi, 'A. 2016. Al-sa'udiyin 'ala mawid al-yawm ma'a ru’ya 2030 al-mustaqbaliya. Al-Arabiya, 25 April. https://bit.ly/1VTlAoo. Accessed 28 Jan 2020.

Al-Muqrin, S. 2018. Shu ur al-imtinan... li-l-mujaddid Muhammad bin Salman. Al-Jazirah, 24 March. http://www.al-jazirah.com/2018/20180324/ar5.htm. Accessed 28 Jan 2020.

Al-Qawi i, S. 'A. 2018. Al-Sa udiyya: quwwa iqlimiyya sa ida. Al-Jazirah, 13 January. http://www.al-jazir ah.com/2018/20180113/ar8.htm. Accessed 28 Jan 2020.

Al-Rasheed, M. 2011. Sectarianism as counter-revolution: Saudi responses to the Arab Spring. Studies in Ethnicity and Nationalism 11 (3): 513-526.

Al-Rasheed, M. 2014. Saudi internal dilemmas and regional responses to the Arab uprisings. In The new middle east: Protest and revolution in the Arab world, ed. F.A. Gerges, 353-379. Cambridge: Cambridge University Press.

Al-Rasheed, M. 2018. King Salman and his son: Winning the USA, losing the rest. In Salman's legacy: The dilemmas of a new era in Saudi Arabia, ed. M. Al-Rasheed, 235-250. London: Hurst.

Al-Rumayhi, M. 2017. Quwwa al-iqna' tatafawwaq 'ala quwwa al-ighwa'. Al-Sharq al-Awsat, 11 March. https://bit.ly/2JBT9Im. Accessed 28 Jan 2020.

Al-Sayyid, R. 2018. Al-mashru' al-'arabi wa-l-tahaddiyat al-kubra. Al-Arabiya, 26 January. https://bit.ly/ 2HQ9k7H. Accessed 28 Jan 2020. 
Al-Tamamy, S.M. 2012. Saudi Arabia and the Arab spring: Opportunities and challenges of security. Journal of Arabian Studies 2 (2): 143-156.

Al-'Utaybi, 'A. 2015. Al-Sa udiyya al-jadida..al-Sa'udiyya al-saida. Al-Sharq al-Awsat, 20 December. https://bit.ly/2HJduuV. Accessed 28 Jan 2020.

Al-Yasin, Y., and A.A. Dashti. 2008. Foreign countries and US public relations firms: The case of three Persian Gulf states. Journal of Promotion Management 14 (3-4): 355-374.

Al-Zamic, R. 2017. Al-tarbush al-turki vs. al-imama al-iraniyya. Al-Arabiya, 31 March. https://bit.ly/ 2r5nY0y. Accessed 28 Jan 2020.

Arabia Foundation. 2017. Four myths of the Qatar crisis. 20 July. http://www.arabiafoundation.org/arabia-comment/four-myths-of-the-qatar-crisis/\#.WXEGcYC-5ok.twitter. Accessed 28 Jan 2020.

Aras, B., and R. Falk. 2015. Authoritarian 'geopolitics' of survival in the Arab spring. Third World Quarterly 36 (2): 322-336.

Bank, A. 2017. The study of authoritarian diffusion and cooperation: Comparative lessons on interests versus ideology, nowadays and in history. Democratization 24 (7): 1345-1357.

Blechman, B.M. 2004. Book review: 'Soft power: The means to success in world politics.' Political Science Quarterly 119 (4): 680-681.

Bos, M., and J. Melissen. 2019. Rebel diplomacy and digital communication: Public diplomacy in the Sahel. International Affairs 95 (6): 1331-1348.

Buzan, B., and O. Wæver. 2003. Regions and powers: The structure of international security. Cambridge: Cambridge University Press.

Çevik, S., and P. Seib, eds. 2015. Turkey's public diplomacy. New York: Macmillan.

Cline, K., P. Rhamey, A. Henshaw, A. Sedziaka, A. Tandon, and T.J. Volgy. 2011. Identifying regional power and their status. In Major powers and the quest for status in international politics, ed. T.J. Volgy, R. Corbetta, K.A. Grant, and R.G. Baird, 133-157. New York: Macmillan.

Cooper, A.F., R.A. Higgot, and K.R. Nossal. 1991. Bound to follow? Leadership and followership in the Gulf conflict. Political Science Quarterly 106 (3): 391-410.

Commins, D. 2006. The Wahhabi Mission and Saudi Arabia. London: I.B. Tauris.

Darwich, M. 2018. The Saudi intervention in Yemen: Struggling for status. Insight Turkey 20 (2): $125-141$.

Darwich, M. 2020. Escalation in failed military interventions: Saudi and Emirati quagmires in Yemen. Global Policy 11 (1): 103-112.

De Luce, D. and Gramer, R. 2018. Congress sours on Saudi Arabia over Yemen. Foreign Policy, 26 March. http://foreignpolicy.com/2018/03/26/saudi-arabia-faces-strong-headwinds-in-congressover-yemen/. Accessed 28 Jan 2020.

Demmelhuber, T. 2019. Playing the diversity card: Saudi Arabia's foreign policy under the Salmans. The International Spectator 54 (4): 109-124.

Department of Justice. n.d.a. https://www.fara.gov/docs/6457-Exhibit-AB-20170830-2.pdf. Accessed 28 Jan 2020.

Department of Justice. n.d.b. https://www.fara.gov/docs/5926-Exhibit-AB-20170815-103.pdf. Accessed 28 Jan 2020.

Department of Justice. n.d.c. https://www.fara.gov/docs/5483-Informational-Materials-20170525-6.pdf. Accessed 28 Jan 2020.

Department of Justice. n.d.d. https://www.fara.gov/docs/5870-Informational-Materials-20170516-3.pdf. Accessed 28 Jan 2020.

Destradi, S. 2010. Regional powers and their strategies: Empire, hegemony, and leadership. Review of International Studies 36 (4): 903-930.

Ebert, H., and D. Flemes. 2018a. Regional leadership and contestation: Strategic reactions to the rise of the BRICS. In Regional powers and contested leadership, ed. H. Ebert and D. Flemes, 1-59. Cham: Macmillan.

Ebert, H., and D. Flemes. 2018b. Rethinking regional leadership in the global disorder. Rising Powers Quarterly 3 (1): 7-22.

Farouk, Y. 2020. Saudi Arabia: Aid as a primary foreign policy tool. In As Gulf donors shift priorities, Arab States Search for aid, ed. M. Dunne. Washington, DC: Carnegie Endowment for International Peace.

Frazier, D.V., and R. Stewart-Ingersoll. 2010. Regional powers and security: A framework for understanding order within regional security complexes. European Journal of International Relations 16 (4): 731-753. 
Frazier, D.V., and R. Stewart-Ingersoll. 2012. Regional powers and regional security orders. London: Routledge.

Gallarotti, G.M., and I.Y. Al-Filal. 2012. Saudi Arabia's soft power. International Studies 49 (3-4): 233-261.

Gause, F.G. 2011. Saudi Arabia's regional security strategy. In International politics of the Persian Gulf, ed. M. Kamrava, 169-183. New York: Syracuse University Press.

Gilboa, E. 2008. Searching for a theory of public diplomacy. Annals of the American Academy of Political and Social Science 616 (1): 55-77.

Gilpin, R. 1981. War and change in world politics. Cambridge: Cambridge University Press.

Hammond, A. 2007. Saudi Arabia's media empire. Arab Media and Society, 1 October. https://www. arabmediasociety.com/saudi-arabias-media-empire-keeping-the-masses-at-home/. Accessed 28 Jan 2020 .

Hall, R. 2019. Saudi Arabia's PR machine and the murder of Jamal Kashoggi. The Independent, 2 October. https://www.independent.co.uk/news/world/middle-east/saudi-arabia-mohammad-binsalman-khashoggi-public-relations-a9129386.html. Accessed 28 Jan 2020.

Hall, S.G.F., and T. Ambrosio. 2017. Authoritarian learning: A conceptual overview. East European Politics 33 (2): 143-161.

Harig, C., and K.M. Kenkel. 2017. Are rising powers consistent or ambiguous foreign policy actors? Brazil, humanitarian intervention and the 'graduation dilemma.' International Affairs 93 (3): 625-641.

Hart, A.F., and B.D. Jones. 2010. How do rising powers rise? Survival 52 (6): 63-88.

Hassan, H. 2018. Qatar won the Saudi blockade. Foreign Policy, 4 June. http://foreignpolicy.com/ 2018/06/04/qatar-won-the-saudi-blockade/. Accessed 28 Jan 2020.

Hertog, S. 2011. Rentier militaries in the Gulf states: The price of coup-proofing. International Journal of Middle East Studies 43 (3): 400-402.

Hinnebusch, R. 2003. The international politics of the middle east. Manchester: Manchester University Press.

Hinnebusch, R. 2013. Failed regional hegemons: The case of the Middle East's regional powers. Seton Journal of Diplomacy and International Relations 14 (2): 75-88.

Hocking, B. 2005. Rethinking the 'new' public diplomacy. In The new public diplomacy: Soft power in international relations, ed. J. Melissen, 28-43. Basingstoke: Macmillan.

Huijgh, E. 2016. Public diplomacy. In Sage handbook of Diplomacy, ed. C.M. Constantinou, P. Kerr, and P. Sharp, 437-450. London: Sage.

Huijgh, E. 2017. Indonesia's 'intermestic' public diplomacy: Features and future. Politics \& Policy 45 (5): 762-792.

Huijgh, E., and C. Byrne. 2012. Opening the windows on diplomacy: A comparison of the domestic dimension of public diplomacy in Canada and Australia. The Hague Journal of Diplomacy 7 (4): 395-420.

Hurrell, A. 2006. Hegemony, liberalism and global order: What space for would-be great powers? International Affairs 82 (1): 1-19.

Hussayn, 'I. 2018. Muhammad bin Salman: Turkiya wa Iran wa-l-mutatarrafin 'mihwar al-sharr aljadid'. Al-Shuruq, 6 March. https://www.shorouknews.com/news/view.aspx?cdate $=06032018 \&$ id=b1b5e661-9097-4a1f-bd71-eaa3c7b7ed55. Accessed 28 Jan 2020.

Ikenberry, G.J., and C.A. Kupchan. 1990. Socialization and hegemonic power. International Organization 44 (3): 283-315.

International Rescue Committee. 2018. Saudi 'aid' plan is war tactic. Press Release, 22 February. https://www.rescue.org/press-release/yemen-saudi-aid-plan-war-tactic. Accessed 28 Jan 2020.

Jesse, N.G., S.E. Lobell, G. Press-Barnathan, and K.P. Williams. 2012. The leaders can't lead when the followers won't follow: The limits of hegemony. In Beyond great powers and hegemons, ed. K.P. Williams, S.E. Lobell, and N.G. Jesse, 1-33. Stanford, CA: Stanford University Press.

Jones, M.O. 2020. Saudi Arabia's bot army flourishes as Twitter fails to tame the beast. Middle East Eye. 20 January. https://www.middleeasteye.net/opinion/despite-twitter-culls-riyadhs-disin formation-network-still-going-strong. Accessed 28 August 2020.

Juneau, T. 2016. Iran's policy towards the Houthis in Yemen: A limited return on a modest investment. International Affairs 92 (3): 647-663.

Kamrava, M. 2013. Mediation and Saudi foreign policy. Orbis 57 (1): 152-170.

Kearn, D.W. 2011. The hard truths about soft power. Journal of Political Power 4 (1): 65-85. 
Keohane, R. 1984. After hegemony: Cooperation and discord in the world political economy. Princeton, NJ: Princeton University Press.

Kneuer, M., and T. Demmelhuber. 2016. Gravity centres of authoritarian rule: A conceptual approach. Democratization 23 (5): 775-796.

Köstem, S. 2018. Different paths to regional hegemony: National identity contestation and foreign economic strategy in Russia and Turkey. Review of International Political Economy 25 (5): $726-752$.

Kraidy, M.M. 2021. Saudi Arabia: From national media to global player. In Arab media systems, ed. C. Richter and C. Kozman, 91-107. Cambridge: Open Book Publishers.

Kunczik, M. 2009. Transnational public relations by foreign governments. In The Global public relations handbook: Theory, research and practice, ed. K. Sriramesh and D. Verčič, 769-794. New York: Routledge.

Lebov, R.N. 2008. A cultural theory of international relations. Cambridge: Cambridge University Press. Lemke, D. 2002. Regions of war and peace. Cambridge: Cambridge University Press.

L'Etang, J. 2009. Public relations and diplomacy in a globalized world. American Behavioral Scientist 53 (4): 607-626.

Lopez-Lucia, E. 2015. Regional powers and regional security governance: An interpretive perspective on the policies of Nigeria and Brazil. International Relations 29 (3): 348-362.

Luck, T. 2016. To counter Iranian rival, Saudi Arabia steps up Washington lobbying. Christian Science Monitor, 8 February. https://www.csmonitor.com/World/Middle-East/2016/0208/To-counter-Irani an-rival-Saudi-Arabia-steps-up-Washington-lobbying. Accessed 28 Jan 2020.

Mattheis, F. 2021. The production of regional order in the seemingly absence of regional powers. International Politics, this issue.

Matthiesen, T. 2015. The Domestic Sources of Saudi Foreign Policy. Washington, DC: Brookings Institution. Working Paper, August.

Matthiesen, T. and Sons, S. 2016. The Yemen war in the Saudi media. Muftah, 20 July. https://muftah. org/yemen-war-saudi-media/\#.WrjlR39CTcv. Accessed 28 Jan 2020.

Mazzetti, M. and Hubbard, B. 2016. Rise of Saudi prince shatters decades of royal tradition. The New York Times, 15 October. https://www.nytimes.com/2016/10/16/world/rise-of-saudi-prince-shattersdecades-of-royal-tradition.html. Accessed 28 Jan 2020.

McVeigh, K. and Summers, H. 2018. 'A national disgrace’: Fury over $£ 100 \mathrm{~m}$ aid deal between UK and Saudi Arabia. The Guardian, 9 March. https://www.theguardian.com/global-development/2018/ mar/09/national-disgrace-fury-over-100m-aid-deal-between-uk-and-saudi-arabia. Accessed 28 Jan 2020.

Melissen, J. 2005. The new public diplomacy: Between theory and practice. In The new public diplomacy: Soft Power in international relations, ed. J. Melissen, 3-27. Basingstoke: Macmillan.

Merrill, J. 2017. Saudi hire world's biggest PR firm to push 'Muslim NATO'. Middle East Eye, 26 April. http://www.middleeasteye.net/news/pr-firm-draws-criticism-over-saudi-deal-represent-muslimnato-1485534964. Accessed 28 Jan 2020.

Nabers, D. 2010. Power, leadership and hegemony in international politics: The case of East Asia. Review of International Studies 36 (4): 931-949.

Nel, P., and M. Stephen. 2010. Agents of change? The foreign economic policies of the IBSA states. In Regional leadership in the global system, ed. D. Flemes, 71-90. Farnham: Ashgate.

Nichols, M. 2017. UN says world needs to know about Yemen, journalists need access. Reuters, 19 July. https://www.reuters.com/article/us-yemen-security-flight-un/u-n-says-world-needs-to-know-aboutyemen-journalists-need-access-idUSKBN1A426N. Accessed 28 Jan 2020.

Nolte, D. 2010. How to compare regional powers: Analytical concepts and research topics. Review of International Studies 36 (4): 881-901.

Nonneman, G. 2005. Determinants and patters of Saudi foreign policy. In Saudi Arabia in the balance, ed. P. Aarts and G. Nonnneman, 315-351. London: Hurst.

Norloff, C. 2017. Hegemony, hierarchy, and unipolarity: Theoretical and empirical foundations of hegemonic order studies. Oxford Research Encyclopedia of Politics. https://doi.org/10.1093/acrefore/ 9780190228637.013.552.

Nye, J.S. 2004. Soft power: The means to success in world politics. New York: Public Affairs.

Nye, J.S. 2008a. The powers to lead. New York: Oxford University Press.

Nye, J.S. 2008b. Public diplomacy and soft power. Annals of the American Academy of Political and Social Science 616 (1): 94-109.

Nye, J.S. 2009. Get smart: Combining hard and soft power. Foreign Affairs 88 (4): 160-163. 
Nye, J.S. 2011. The future of power. New York: Public Affairs.

Ogunnubi, O., and U. Okeke-Uzodike. 2016. Can Nigeria be Africa's hegemon? African Security Review 25 (2): 110-128.

Østerud, Ø. 1992. Regional great powers. In Regional great powers in international politics, ed. I.B. Neumann, 1-15. Basingstoke: St. Martin's Press.

Pajpaee, C. 2017. The birth of multipolar Asia? Lowy Institute, 2 May. https://www.lowyinstitute.org/theinterpreter/birth-multipolar-asia. Accessed 28 Jan 2020.

Partrick, N. 2016. Conclusion. In Saudi Arabian foreign policy: Conflict and cooperation, 374-376. London: I.B. Tauris.

Pedersen, T. 2002. Co-operative hegemony: Power, ideas and institutions in regional integration. Review of International Studies 28 (4): 677-696.

Peterson, J.E. 2002. Saudi Arabia and the illusion of security. London: Oxford University Press.

Prys, M. 2010. Hegemony, domination, detachment: Differences in regional powerhood. International Studies Review 12 (4): 479-504.

Prys, M. 2012. Redefining regional power in international relations: Indian and South African perspectives. London: Routledge.

Rieger, R. 2016. Saudi Arabian foreign relations: Diplomacy and mediation in conflict resolution. London: Routledge.

Russet, B.M. 1985. The mysterious case of vanishing hegemony, or, is Mark Twain really dead? International Organization 36 (2): 207-234.

Salih, H. 2017. Hal min majal li-1-muqarana? Al-Sharq al-Awsat, 31 October. https://bit.ly/2rb6akj. Accessed 28 Jan 2020.

Sauer, S., M.V. Balestro, and S. Schneider. 2017. The ambiguous stance of Brazil as a regional power: Piloting a course between commodity-based surpluses and national development. Globalizations 15 (1): 32-55.

Sciutto, J. and Herb, J. 2017. The secret documents that help explain the Qatar crisis. CNN, 11 July. https://edition.cnn.com/2017/07/10/politics/secret-documents-qatar-crisis-gulf-saudi/index. html. Accessed 28 Jan 2020.

Serrão, O., and P.-H. Bischoff. 2009. Foreign policy ambiguity on the part of an emergent middle power: South African foreign policy through other lenses. Politikon 36 (3): 363-380.

Sick, G. 2017. The Siege of Doha. Lobe Log, 16 June. https://lobelog.com/the-siege-of-doha/. Accessed 28 Jan 2020.

Signitzer, B., and T. Coombs. 1992. Public relations and public diplomacy: Conceptual divergence. Public Relations Review 18 (2): 137-147.

Signitzer, B., and C. Wamser. 2006. Public diplomacy: A specific governmental public relations function. In Public Relations Theory II, ed. C.H. Botan and V. Hazleton, 453-464. Mahwa, NJ: Lawrence Erlbaum Associates.

Singh, A., and A. Sarwal. 2017. Paraspara, encounters, and confluences: India's soft power objective in the Indo-Pacific region. Politics \& Policy 45 (5): 733-761.

Sokolove, M. 2019. Why Is There So Much Saudi Money in American Universities. The New York Times, 3 July. https://www.nytimes.com/2019/07/03/magazine/saudi-arabia-american-universiti es.html. Accessed 28 Jan 2020.

Spanier, G. 2018. Saudi crown prince launches ad blitz to promote London visit. Campaign, 6 March. https://www.campaignlive.co.uk/article/saudi-crown-prince-launches-ad-blitz-promote-londonvisit/1458702. Accessed 28 Jan 2020.

Srimamesh, K., and D. Verčič. 2009. A theoretical framework for global public relations research and practice. In The global public relations handbook: Theory, research and practice, ed. $\mathrm{K}$. Sriramesh and D. Verčič, 3-21. New York: Routledge.

Sunik, A. 2018. Regional leadership in authoritarian contexts: Saudi Arabia's new military interventionism as part of its leadership bid in the Middle East. Rising Powers Quarterly 3 (1): 65-85.

Tago, A. 2017. Public diplomacy and foreign policy. Oxford Research Encyclopedia of Politics. https://doi.org/10.1093/acrefore/9780190228637.013.471.

Tansey, O., K. Koehler, and A. Schmotz. 2017. Ties to the rest: Autocratic linkages and regime survival. Comparative Political Studies 50 (9): 1221-1254.

UN Office at Geneva. 2018. Remarks by the Secretary-General to the Pledging Conference on Yemen. 2 April. https://www.unog.ch/unog/website/news_media.nsf/(httpNewsByYear_en)/27F6C CAD7178F3E9C1258264003311FA?OpenDocument. Accessed 28 Jan 2020.

UN Security Council. 2017. Final Report of the Panel of Experts on Yemen. S/2018/193, 27 January.

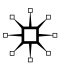


US Department of State. 2018. Joint Statement of the Inaugural United States-Qatar Strategic Dialogue. 30 January. https://qa.usembassy.gov/joint-statement-inaugural-united-states-qatar-strat egic-dialogue/. Accessed 28 Jan 2020.

Volgy, T.J., P. Bezerra, J. Cramer, and J.P. Rhamey. 2017. The case for comparative regional analysis in international politics. International Studies Review 19 (3): 452-480.

von Soest, C. 2015. Democracy prevention: The international collaboration of authoritarian regimes. European Journal of Political Research 54 (4): 623-638.

White House. 2018. Remarks by President Trump on the Joint Comprehensive Plan of Action. 8 May. https://www.whitehouse.gov/briefings-statements/remarks-president-trump-joint-comprehensiveplan-action/. Accessed 28 Jan 2020.

Wigell, M. 2016. Conceptualizing regional powers' geoeconomic strategies: Neo-imperialism, neo-mercantilism, hegemony, and liberal institutionalism. Asia Europe Journal 14 (2): 135-151.

Wilson, E.J., III. 2008. Hard power, soft power, smart power. Annals of the American Academy of Political and Social Science 616 (1): 110-124.

World Peace Foundation. 2016. African Politics, African peace: Report submitted to the African Union. Medford, MA: World Peace Foundation.

Zumbrägel, T., and T. Demmelhuber. 2020. Temptations of autocracy: How Saudi Arabia influences and attracts its neighbourhood. Journal of Arabian Studies 10 (1): 51-71.

Yaghi, M. 2017. Media and sectarianism in the middle east: Saudi hegemony over pan-Arab media. International Journal of Media \& Cultural Politics 13 (1-2): 39-56.

Young, O.R. 1991. Political leadership and regime formation: On the development of institutions in international society. International Organizations 45 (3): 281-308.

Publisher's Note Springer Nature remains neutral with regard to jurisdictional claims in published maps and institutional affiliations. 